УДК 633.8:581.524.1:581.192.7

(C) 2011

Поспелов С. В., кандидат сільськогосподарських наук, Шериова С. В., аспірант *

Полтавська державна аграрна академія

\title{
ДОСЛІДЖЕННЯ БІОЛОГІЧНОЇ АКТИВНОСТІ ЛЕКТИНВМІСНИХ ЕКСТРАКТІВ ЕХІНАЦЕЇ ПУРПУРОВОЇ (Echinacea purpurea (L.) Moench.)
}

\section{Рецензент - кандидат сільськогосподарських наук Г. Д. Поспєлова}

Вивчено біологічну активність лектинвмісних екстрактів ехінацеї пурпурової (Echinacea ритригеа (L.) Moench.) та їх складових иляхом тестування на паростках крес-салату. Доведено, щзо лектини, які містяться в екстрактах усіх видів сировини, пригнічують тест-систему в концентрації 10-

0,1\%. У подальших розведеннях екстракти листків та стебел ехінацеї пурпурової не впливають або несуттєво пригнічують ріст паростків крессалату. Нативний екстракт кореневищ із коренями в концентраціях $10^{-1}-10^{-4} \%$ слабо стимулював, а в подальших розведеннях - інгібував тест-об' єкт. Тестування екстрактів суцввіть ехінацеї пурпурової показало стимуляцію паростків до $+25 \%$ відносно контролю в концентраціях $10^{-2}-10^{-8} \%$. Робиться

висновок, щзо дія білкових компонентів більше пригнічує, ніж стимулює тест-об'єкт.

Ключові слова: Ехіначея пурпурова, Echinacea purpurea (L.) Moench., Зірка Миколи Вавилова, етанольне фракиіонування, лектини, нативні екстракти, біологічна активність, тестсистема.

Постановка проблеми. Ехінацея пурпурова (Echinacea purpurea (L.) Moench.) входить до першої десятки лікарських рослин за їх використанням у світі. Завдяки унікальному хімічному складу надземна маса та кореневище 3 коренями $\epsilon$ сировиною для виготовлення препаратів, що мають імуностимулюючі властивості й використовуються в гуманітарній та ветеринарній медицині як біологічно активні добавки [4]. В останні роки активно вивчаються ії властивості як природного регулятора росту і розвитку рослин [3].

3-поміж білкових речовин, що містяться в рослинах, особливе місце займають лектини. Відомо, що вони відповідають за різноманітні важливі фізіологічні процеси в рослині: утворення бульбочок на коренях бобових, запилення, транспорт пластичних речовин, реакції імуніте- ту, реакції пізнавання тощо [5]. Доведено, що ехінацея пурпурова містить дані специфічні білки, але їх біологічна активність до цього раніше не вивчалася [7].

Саме тому метою наших досліджень було вивчення біологічної активності лектинвмісних екстрактів ехінацеї пурпурової та їх складових.

Аналіз основних досліджень і публікацій, у яких започатковано розв'язання проблеми. Лектини - самостійна група білків, які вперше були отримані завдяки їх здатності зворотно й вибірково зв'язувати вуглеводи та вуглеводні ліганди біополімерів [2]. Більшість гіпотез про функції лектинів грунтується на наявності в їх складі доменів, що зв 'язують вуглеводи, але питання фізіологічної ролі лектинів рослин на даний час ще не з'ясоване [5]. Безсумнівно, що специфічна лектин-вуглеводна взаємодія є універсальним молекулярним механізмом, що лежить в основі цілої низки фізіологічних процесів. На сьогодні експериментально доведено, що лектини беруть участь у захисті від чужорідних організмів, у формуванні відповіді на негативний вплив оточуючого середовища, у процесах диференціації клітин, росту та розвитку рослин [6].

Встановлено, що білки, які володіють лектиновою активністю, містяться в різних органах ехінацеї пурпурової [7]. Активність екстрактів різних частин i органів ехінацеї пурпурової може значно відрізнятися залежно від способу екстракції, методики визначення активності та інших чинників [8].

Мета досліджень та методика їх проведення. Метою наших досліджень було вивчення біологічної активності сировини ехінацеї пурпурової. Для цього використовували повітряносухі зразки різних частин та органів ехінацеї пурпурової сорту «Зірка Миколи Вавилова», культивованої в Полтавській області.

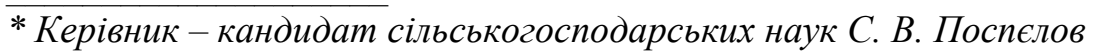


Екстракцію проводили фізіологічним розчином протягом двох годин, за співвідношення сировини та фізіологічного розчину 1:10. Після цього з витяжок методом низькотемпературного етанольного фракціонування отримували білкові сполуки, що випадали в осад. Інші компоненти залишалися в надосадковій рідині. Біологічну активність нативних екстрактів, а також їх компонентів визначали за методом А. М. Гродзинського на паростках крес-салату [1]. Отримані екстракти та їх складові вивчалися у концентраціях $10-10^{-8} \%$.

Результати дослідження та їх обговорення. Нами вивчалася біологічна активність нативних екстрактів листків, суцвіть, стебел і кореневищ із коренями та їх складових ехінацеї пурпурової сорту «Зірка Миколи Вавилова». Слід зазначити, що в усіх зразках простежується загальна закономірність - інгібування екстрактами та їх складовими паростків крес-салату в концентраціях 10 та $1 \%$. При цьому повне зупинення ростових процесів тест-культури (100 \% відносно контролю) спричиняли екстракти листків і суцвіть ехінацеї пурпурової в концентрації $10 \%$.

Результати впливу лектинвмісних екстрактів листків та їх складових на паростки крес-салату наведено на рисунку 1 . У концентрації 1-0,1\% пригнічуюча дія нативного екстракту забезпечувалася передусім дією білкових компонентів, що випадали у осад, аніж речовинами, що залишалися у супернатанті. В розведеннях $10^{-2}-10^{-5} \%$ екстракти та їх складові проявляли незначну біологічну активність (від -7 \% до $+3,5 \%$ до контролю). Заслуговує на увагу, що екстракти при більш високому розведенні (в концентраціях $10^{-6}-10^{-8} \%$ ) гальмували проростання паростків крес-салату на $-8,5-26,0 \%$. У той же час білкові компоненти та екстракти без лектинів мали менш виражену активність. Таким чином екстракт із листків ехінацеї пурпурової лише в концентраціях 10-0,1\% має виражену біологічну активність на тестсистему.

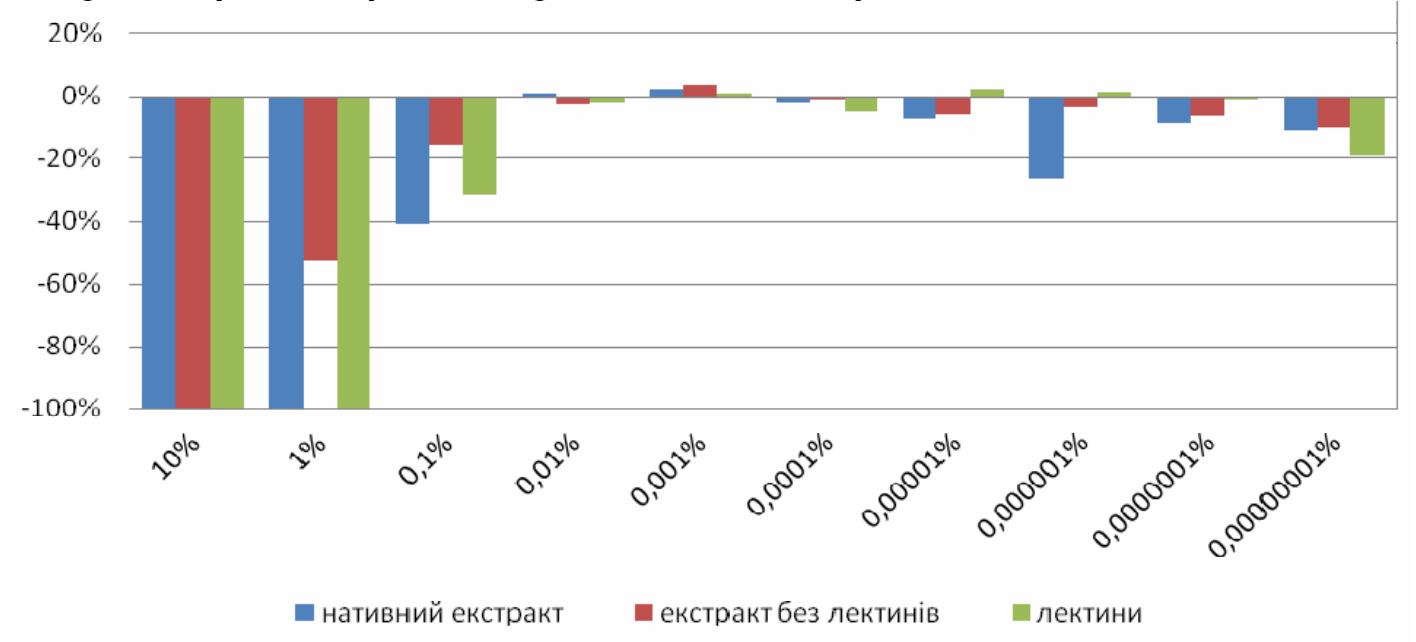

Рис. 1. Біологічна активність нативного екстракту листків ехінацеї пурпурової та його складових

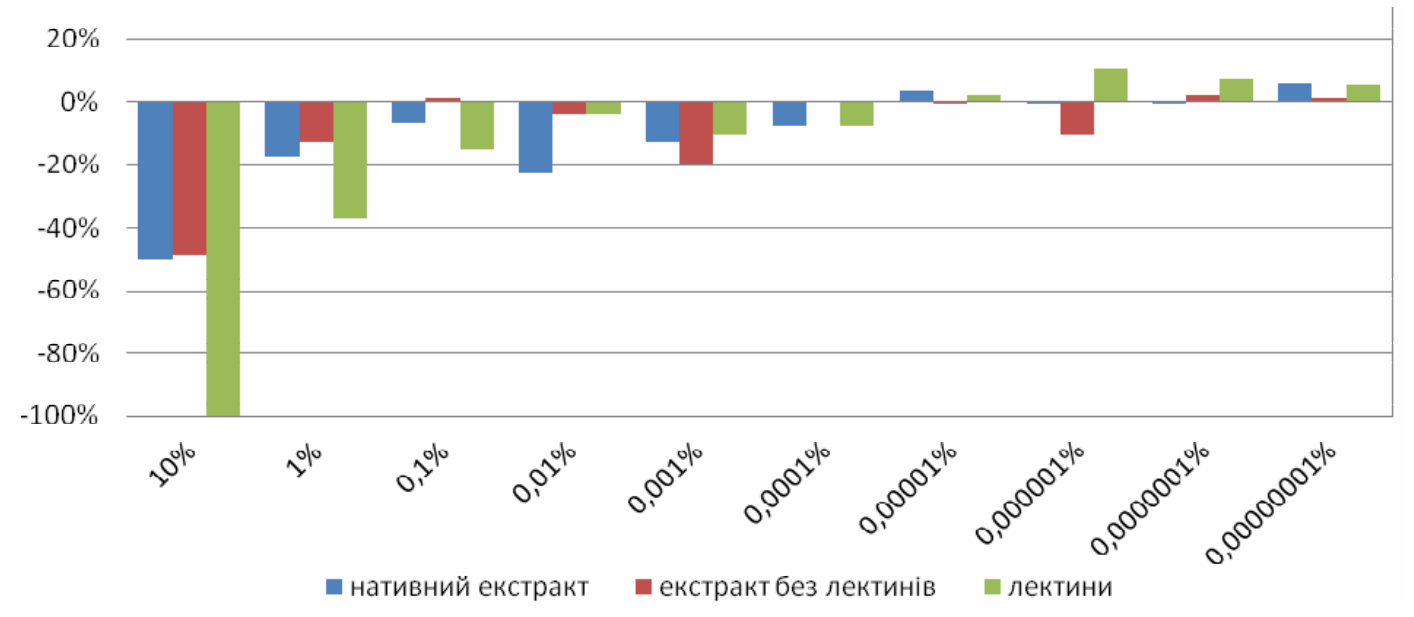

Рис. 2. Біологічна активність нативного екстракту стебел ехінацеї пурпурової та його складових 
Проведені дослідження біологічної активності екстрактів стебел ехінацеї пурпурової свідчать, що пригнічуюча дія нативного екстракту у концентраціях 10-0,1\% зумовлена дією лектинів (рис. 2). При подальших розведеннях $\left(10^{-2}-10^{-4}\right)$ активність нативного екстракту більше відповідала дії екстракту без лектинів. Незначна стимулююча дія екстрактів і білкових сполук (близько $10 \%$ відносно контролю) спостерігалася при розведенні до $10^{-5}-10^{-8} \%$. У цілому екстракти стебел ехінацеї пурпурової та їх складові гальмували тест-об'єкт.

Дані, що наведені на рисунку 3, свідчать про характерну залежність біологічної активності екстрактів (передусім білкових компонентів, що містяться у них) від концентрації розчинів. Нативний екстракт кореневищ із коренями ехінацеї пурпурової та їх складові у концентраціях (10$1 \%$ суттєво інгібували дослідні паростки. При цьому лектини проявляли більшу активність $(-41,2-100 \%)$ порівняно з нативним екстрактом та екстрактом без лектинів (-15,7-67,3 \%). При подальших розведеннях у діапазоні концентрацій $10^{-2}-10^{-4} \%$ спостерігалась стимуляція $(+7,2-$ $15,7 \%)$, а в подальших розведеннях - пригнічення паростків крес-салату $(-2,6-24,8 \%)$. Така зміна напряму дії екстрактів i, особливо, їх дії у великих розведеннях, на нашу думку, може бути пов'язана 3 наявністю фізіологічно активних речовин гормональної природи чи/та комплексу алелопатично активних речовин різнобічної дії, що підтверджується дослідженнями українських фізіологів [1].

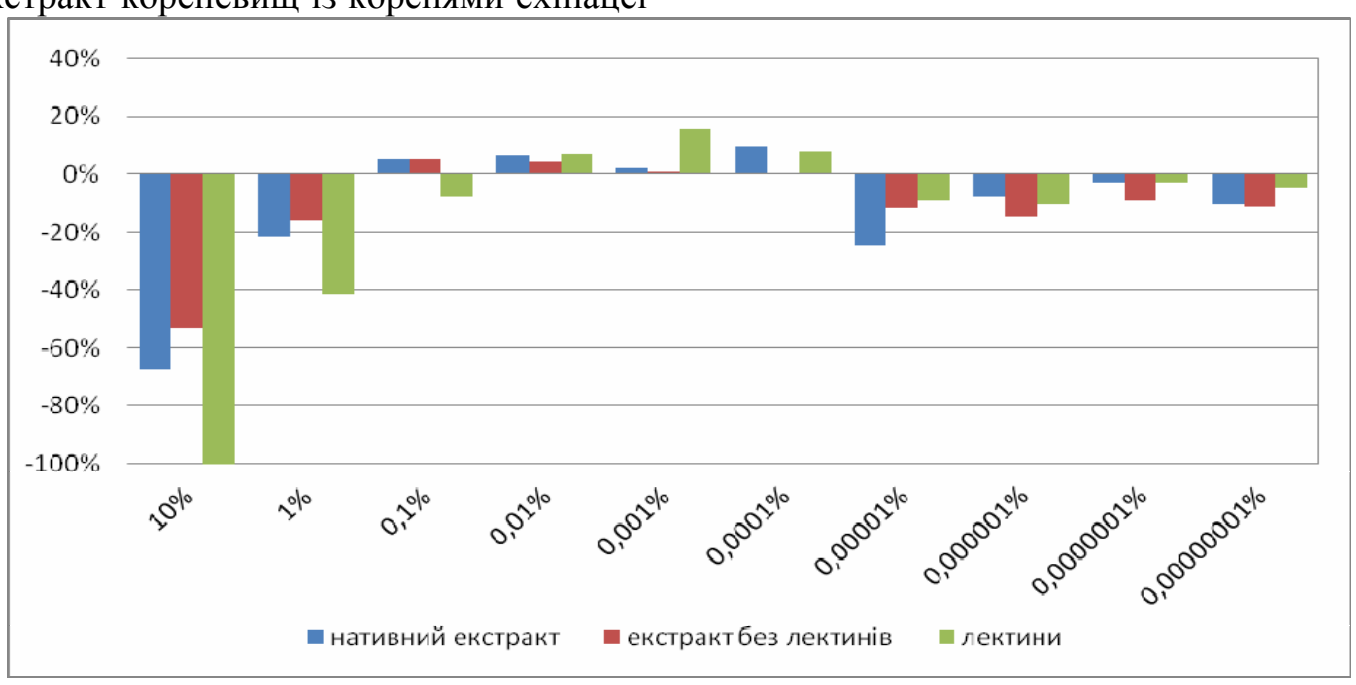

Рис. 3. Біологічна активність нативного екстракту кореневищ із коренями ехінацеї пурпурової та його складових

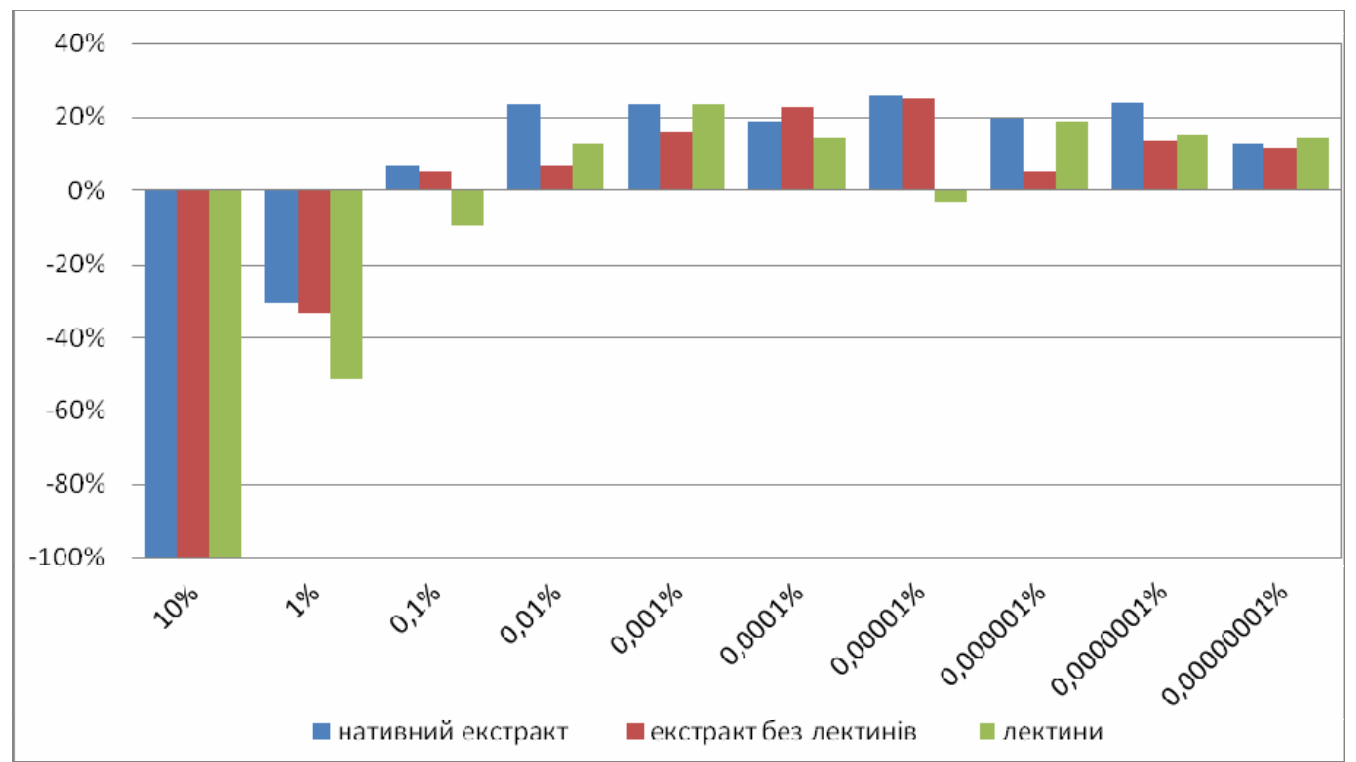

Рис. 4. Біологічна активність нативного екстракту суцвіть ехінацеї пурпурової та його складових 
Дослідження біологічної активності екстрактів суцвіть ехінацеї пурпурової показало його високу біологічну активність (рис. 4). У концентраціях 10-1\% спостерігався гальмівний вплив нативного екстракту та компонентів (-30-100\%) до контролю, що характерно й для інших зразків сировини. В подальших розведеннях спостерігається стабільна позитивна дія екстрактів на тестсистему. Варто зауважити, що в концентраціях $10^{-1}-10^{-8} \%$ активність нативного екстракту переважно визначалася сумарною дією його компонентів. При цьому стимуляція становила $+13-26 \%$ відносно контролю.

Висока й тривала дія екстракту суцвіть на паростки крес-салату дає нам підставу 3 часом провести більш глибокі дослідження біологічної активності сполук, що містяться в суцвіттях ехінацеї пурпурової.

3 метою визначення зв'язку між дією нативного екстракту та його складових були визначені коефіцієнти лінійної кореляції між значеннями біологічної активності (рис. 5). Так, для екстракту листків найбільший коефіцієнт кореляції був виявлений між лектинами та екстрактом без лектинів $(\mathrm{r}=0,98)$. У той же час коефіцієнт кореляції між нативним екстрактом і лектинами, що містяться в ньому, складає r=0,94, а екстрактом без

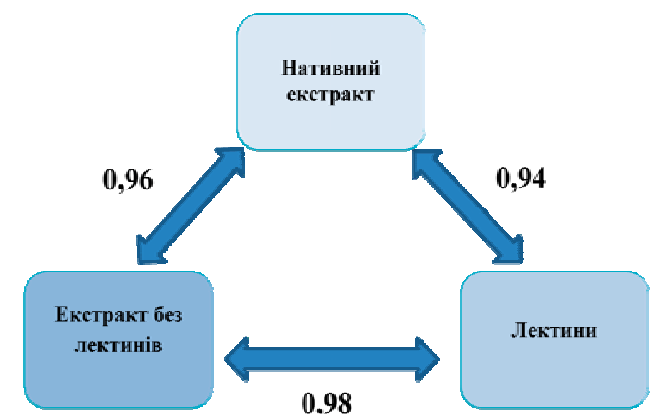

Листки

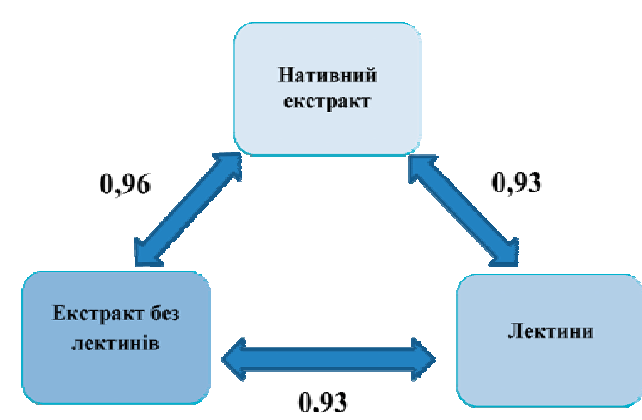

Корені лектинів $\mathrm{r}=0,96$. Отже, більша взаємодія спостерігається між білковими компонентами й екстрактом без лектинів порівняно $з$ нативним екстрактом.

Взаємодія між дією нативного екстракту стебел ехінацеї пурпурової та лектинами становила $\mathrm{r}=0,86$, екстрактом без лектинів - $\mathrm{r}=0,82$, що свідчить про незбалансовану біологічну активність екстрактів у досліді.

Кореляційний аналіз біологічної активності нативних екстрактів та його компонентів із коренів і суцвіть ехінацеї пурпурової показує високий ступінь зв'язку між ними. Так, коефіцієнт кореляції між нативними екстрактами кореневищ із коренями та його компонентами змінювався від $\mathrm{r}=0,93$ до $\mathrm{r}=0,96$, а екстрактів суцвіть $\mathrm{r}=0,91-0,98$.

Таким чином, розраховані коефіцієнти кореляції підтверджують, що біологічна активність нативних екстрактів ехінацеї пурпурової залежить як від білкових компонентів, так і речовин, що залишаються в екстрактах після видалення лектинів. Залежно від ступеня розведення вони можуть підсилювати активність або, навпаки, послаблювати ii. Безумовний інтерес для подальших досліджень мають екстракти суцвіть і кореневищ із коренями ехінацеї пурпурової.

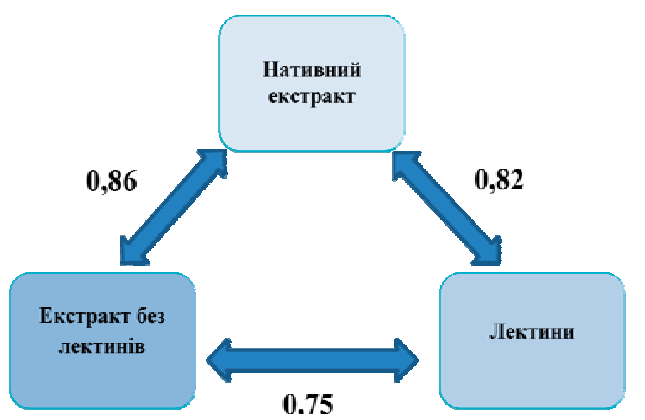

Стебла

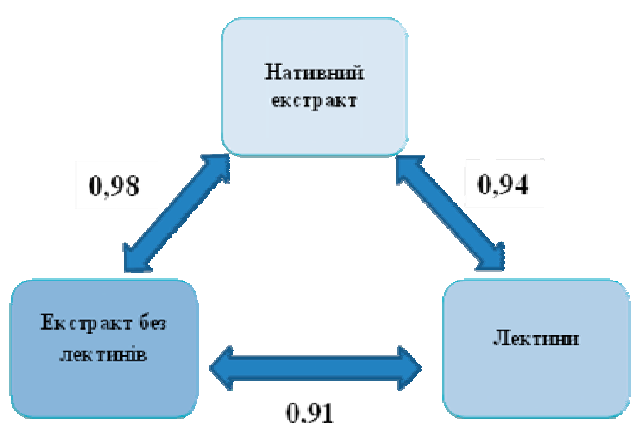

Суцвіття

Рис. 5. Кореляційний аналіз біологічної активності екстрактів ехінацеї пурпурової та ӥх компонентів 


\section{Висновки:}

1. Результати біотестування екстрактів ехінацеї пурпурової свідчать, що пригнічувальна дія нативного екстракту у високих концентраціях зумовлена дією білкових речовин, що містяться в них.

2. Екстракти з листків та стебел ехінацеї пурпурової мають пригнічувальний вплив на корені крес-салату в концентраціях 10-0,01\%, а при подальшому розведенні активність не перевищувала $\pm 12 \%$ до контролю.

\section{БІБЛІОГРАФІЯ}

1. Гродзинский A. M. Аллелопатия растений и почвоутомление: Изб. тр. - К.: Наукова думка, 1991. -432 с.

2. Королев Н. П. Функции лектинов в клетках // Итоги науки и техники. Общие проблемы физико-химической биологии. - М., 1984. - Т. 1. C. 59-96.

3. Луичик М. Д., Панасюк Е. Н., Луичик А. Д. Лектины. - Львов: Вища школа, 1981.-156 с.

4. Мищенко О. В., Головко Э. А., Поспелов С. В. Особенности аллелопатической активности эхинацеи пурпурной первого и второго годов вегетации // Інтродукція рослин. - 2005. - №4. C. 88-92.

5. Поспелов С. В., Самородов В. Н. Поиски и свойства лектинов эхинацеи пурпурной // Про-
3. Встановлено, що біологічна активність нативного екстракту кореневищ із коренями до розведення $10^{-3} \%$ визначалася білковими компонентами, а в подальших розведеннях - переважно небілковими речовинами.

4. Тестування екстрактів суцвіть ехінацеї пурпурової показало високу гальмівну дію нативного екстракту та його компонентів у концентраціях 10-1\%. Проте в розведеннях $10^{-1}-10^{-8} \%$ спостерігалася стимуляція паростків крес-салату до $+25 \%$ відносно контролю.

блеми лікарського рослинництва / Тез. доп. Міжнар. наук.-практ. конф. 3 нагоди 80-річчя УлР УААН. - Полтава, 1996. - С. 239-240.

6. Поспелов С. В. Оценка активности лектинсодержащих экстрактов эхинацеи пурпурной // Вісник Полтавського державного сільськогосподарського інституту - 1998. - №1. - С. 15-17.

7. Самородов В. Н., Поспелов С. В., Моисеева Г. Ф.

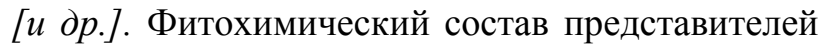
рода Эхинацея (Echinace Moench) и его фармакологические свойства // Хим.-фармацевтич. журн. - 1996. - № 4. - С. 32-37.

8. Ямалеева A. А. Лектины растений и их биологическая роль / Автореф. дис. ... д-ра биол. наук. - СПб, 2002. - 50 с. 